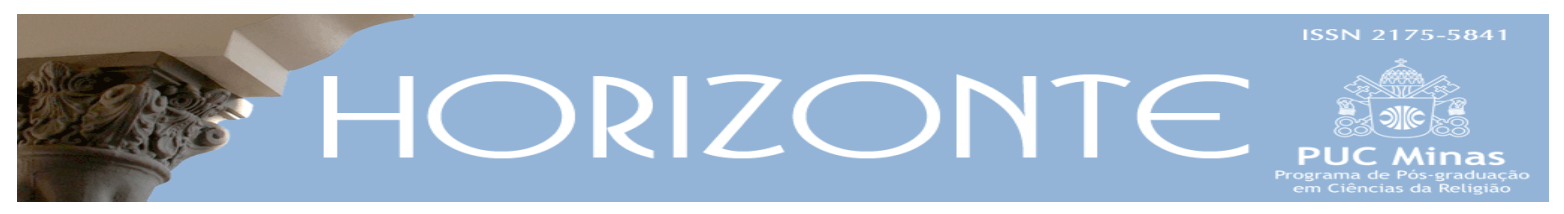

Dossiê: Narrativas Sagradas e Linguagens Religiosas - Artigo Original ๑。을

\title{
O cânon bíblico: \\ por que certas narrativas se tornaram sagradas?
}

\author{
The Canon: Why have certain narratives become sacred texts?
}

\author{
Antonio Geraldo Cantarela*
}

\begin{abstract}
Resumo
O artigo aborda questões relacionadas à formação do cânon bíblico judaico-cristão. Propõe-se a discutir, em seu foco mais amplo, por que e de que modo a Bíblia é ou tornou-se livro sagrado. De modo mais específico, destaca alguns traços das teologias que subsidiaram a delimitação do cânon judaico e do cânon cristão. Aponta o caráter de normatividade que o cânon constrói para os seguidores do judaísmo e do cristianismo. Destaca ainda algumas informações históricas relativas aos momentos em que, primeiro, a Bíblia judaica e, depois, a Bíblia cristã alcançaram seu status canônico definitivo. Na abordagem que entrelaça aspectos teológicos e históricos da formação do cânon, destacam-se, dentre outros pontos, as concepções teológicas de revelação e palavra de Deus, a centralidade teológica da Lei (Torá) para a comunidade judaica, a fidelidade dos Profetas (Nebiim) à tradição mosaica, a releitura da Torá realizada pelos sábios com seus Escritos (Ketubim), por Jesus de Nazaré e pelas primeiras comunidades cristãs.
\end{abstract}

Palavras-chave: Narrativa sagradas. Cânon. Bíblia judaica. Bíblia cristã. Palavra de Deus.

\begin{abstract}
The paper deals with topics related to the formation of the Jewish - Christian canon. The aim of this piece of work is to discuss widely why and how the Bible is or it became a sacred book. In a more specific way, it highlights some features of the theologies that helped to mark the Jewish and the Christian canon. The paper also discusses the normative nature the canon builds for the followers of Judaism and Christianity. Furthermore, it shows some historical information related to moments when both, first the Hebrew Bible and later the Christian Bible, reached their ultimate canonic status. Some of the elements studied in this approach, that combines theological and historical aspects of the formation of the canon, are the theological concepts of revelation and the Word of God, the theological centrality of the Law (Torah) for the Hebrew community, the loyalty of the Prophets (Nebhi'im) to Mosaic tradition, the rereading of Torah conducted by the wisemen with their Writings (Kethubi'im), by Jesus of Nazareth and by the first Christian communities.
\end{abstract}

Key-words: Sacred narrative. Canon. Hebrew Bible. Christian Bible. Word of God.

Artigo recebido em 06 de maio de 2016 e aprovado em 31 de maio de 2016.

* Doutorado em Letras (Literatura) pela Pontifícia Universidade Católica de Minas Gerais. Professor Adjunto da Pontifícia Universidade Católica de Minas Gerais. Departamento de Ciências da Religião. País de Origem: Brasil. E-mail: agcantarela@yahoo.com.br

Horizonte, Belo Horizonte, v. 14, n. 42, p. 315-336, abr./jun. 2016 - ISSN 2175-5841 


\section{Introdução}

As narrativas sagradas das tradições religiosas apresentam-se, em geral, como corpus acabado, ao qual não se permitem acréscimos ou exclusões. Nas religiões que se identificam por possuir um livro sagrado, este se constitui de um cânon ou lista completa e fechada de escritos que ocupam lugar de importância na existência dos seguidores daquela religião. Tal importância se destaca de modo particular nos momentos celebrativos realizados pelos ritos e cultos; e, no cotidiano, no caráter de normatividade exigido pela palavra sagrada escrita.

A delimitação de um corpus de narrativas configurando um cânon sagrado apresenta-se como uma questão de grande importância para o âmbito da teologia, particularmente porque ao cânon se associam constructos teológicos fundamentais, como, dentre outros, a afirmação de um Deus que se nos revela, a correlata categoria "palavra de Deus" e o memorial sagrado que busca dar conta das origens de determinado povo ou instituição.

Este artigo propõe-se a abordar algumas questões relativas a fatores que levaram certas narrativas a ocupar lugar nos cânones sagrados. Alguns dos aspectos sobre os quais vamos nos deter - como santidade e normatividade dos escritos sagrados -, por sua amplitude e generalidade, podem ser encontrados em quaisquer tradições religiosas. De qualquer modo, tomaremos como referência para a discussão apenas a experiência judaico-cristã. Assim, nossa pergunta central será: por que e como a Bíblia (o conjunto dos escritos do Primeiro e do Segundo Testamento) é ou tornou-se livro sagrado?

A discussão do tema transitará entre o viés teológico, que recebe mais ênfase, e o histórico, destacando alguns aspectos que servirão de estrutura ao artigo: i) que critérios teológicos definiram a santidade de alguns textos, fazendo com que estes fossem acolhidos no cânon bíblico? ii) que aspectos de normatividade, oriundos da leitura dos textos santos, estiveram presentes nas 
construções identitárias do judaísmo e do cristianismo? $\mathrm{Na}$ conclusão destacaremos algumas questões relacionadas à formação do cânon bíblico.

\section{Revelação, palavra de Deus e escrituras sagradas}

Na base da formação dos cânones dos livros sagrados encontra-se, em geral, alguma concepção de revelação de Deus aos homens. Com certa frequência, a categoria "revelação" apresenta-se na forma de narrativa mítica segundo a qual determinada divindade deu-se a conhecer a determinado povo, exigindo-lhe fidelidade e culto; ou se revelou a um profeta, enviando-o a realizar alguma missão em prol do seu povo.

Ao que indicam as pesquisas sobre o assunto, foi assim também com a Bíblia. Dados históricos e arqueológicos do mundo bíblico e de seu entorno sugerem que o culto a Javé ${ }^{1}$ (e, paralelamente, a outros baalim ${ }^{2}$ ) sustenta-se sobre mitos fundadores segundo os quais os deuses, reunidos, repartiram entre si os povos, para que cada divindade pudesse receber com justeza o seu culto. Infelizmente, não dispomos dessas narrativas míticas na sua inteireza originária. Mas podemos encontrar seus resíduos em inúmeras passagens da Bíblia. 3 Bastaria uma leitura rasa do chamado segundo discurso de Moisés (em Deuteronômio 4,44 a 11,32) para encontrarmos inúmeros versos que fazem referência a Javé como o Deus que se ligou a Israel e o escolheu; Deus único, perante o qual Israel não deverá ter outros deuses; Deus zeloso de sua herança e, por causa dela, ciumento. No cântico de Moisés (em Deuteronômio 32, 8-9) encontramos de forma expressa o imaginário sobre a repartição das nações, cabendo a Javé o quinhão representado por Jacó/Israel. Igualmente, no Salmo 135 lemos que “Javé escolheu Jacó para si” (Sl 135, 4). Trata-se, na história da religião do antigo Israel, de uma concepção

\footnotetext{
${ }^{1}$ Optamos por substituir a grafia "lahweh", adotada pela Bíblia de Jerusalém, pela forma mais simples "Javé", mesmo nas citações literais dessa tradução.

2 Plural de Baal, que na língua hebraica quer dizer Senhor. Era o nome genérico com que se designavam divindades do panteão fenício/cananeu.

${ }^{3}$ Para a discussão acerca dos empréstimos bíblicos tomados junto a antigos cultos cananeus, pode-se ler Gunneweg, 2005. Os capítulos iniciais da obra abordam a religião cananeia e a religião dos patriarcas. Sobre a realeza de Javé acima de outros deuses, concepção típica do período do Israel estatal, leia-se o capítulo IV, particularmente as páginas 190 e seguintes.
}

Horizonte, Belo Horizonte, v. 14, n. 42, p. 315-336, abr./jun. 2016 - ISSN 2175-5841 
monolátrica de Deus, segundo a qual Javé, a divindade da nação, “ultrapassa”, “é maior”, "mais terrível”, “está acima” dos outros deuses. Pode-se ler, para ilustrar a afirmação, Salmos 95,3; 96,4; 97,7-9 e inúmeras outras passagens.

Ao nos referirmos à ideia de revelação, subjacente às passagens bíblicas citadas e presente também em narrativas de outras tradições religiosas, não colocamos em discussão o caráter de pretensão à verdade que os discursos teológicos sobre revelação encerram. As tentativas do pensamento racionalista moderno em deslegitimar a pretensão à verdade dos discursos teológicos redundaram em fracasso; simplesmente porque os discursos relativos à revelação e à fé não pertencem ao âmbito das ciências - cujo estatuto se sustenta no critério de falsificabilidade das proposições. Ora, não se pode refutar que Deus tenha se revelado aos homens. Ao discutir a questão do critério de demarcação entre ciência e "não ciência”, seguindo Karl Popper, Luc Ferry (2011, p. 93) ilustra a discussão afirmando que "não se pode imaginar nenhuma experiência, nenhum teste que venha contradizer” a hipótese de que Deus existe. Assim, pois, em consonância com as demarcações indicadas por esses teóricos, afirmamos a revelação de Deus como verdade de fé, do tipo que não pode ser refutada pelos métodos das ciências. Apoiados sobre esses pressupostos, voltemos ao tema.

\subsection{Revelação, aliança e Torá}

Na tradição judaica, a revelação de Deus exprime-se como presença inefável e terrificante, a qual Israel não pode suportar. Inúmeras passagens bíblicas, algumas pertencentes a extratos muito antigos, falam do temor de Israel perante a teofania de Javé. Na cena da aliança no Sinai, narrada em Êxodo 19-20, a teofania é assim descrita:

Ao amanhecer, desde cedo, houve trovões, relâmpagos e uma espessa nuvem sobre a montanha, e um clamor muito forte de trombeta; e o povo que estava no acampamento pôs-se a tremer. Moisés fez o povo sair do acampamento ao encontro de Deus, e puseram-se ao pé da montanha. Toda a montanha do Sinai fumegava, porque Javé descera sobre ela no 
fogo; a sua fumaça subiu como a fumaça de uma fornalha, e toda a montanha tremia violentamente. O som da trombeta ia aumentando pouco a pouco; Moisés falava e Deus lhe respondia do trovão. Javé desceu sobre a montanha do Sinai, no cimo da montanha. Javé chamou Moisés para o cimo da montanha, e Moisés subiu. (Ex 19, 16- 20).

A cena continua (Ex 19,21-25) com a advertência para que o povo "não ultrapasse os limites para vir ver Javé, para muitos deles não perecerem". Segue-se o decálogo (em Êxodo 20), iniciado com as palavras que indicam a origem divina dos ordenamentos: "Deus pronunciou todas estas palavras, dizendo: 'Eu sou Javé teu Deus que te fez sair da terra do Egito, da casa da escravidão'.” Ao final, a perícope reitera a ideia da presença terrível de Javé e o medo do povo, razão pela qual caberá a Moisés o papel de mediador da aliança. Diz o texto bíblico:

Todo o povo, vendo os trovões e os relâmpagos, o som da trombeta e a montanha fumegante, teve medo e ficou longe. Disseram a Moisés: 'Falanos tu, e nós ouviremos; não nos fale Javé, para que não morramos.' Moisés disse ao povo: 'Não temais. Deus veio para vos provar e para que o seu temor esteja diante de vós, e não pequeis.' O povo ficou longe; e Moisés aproximou-se da nuvem escura, onde Deus estava. (Ex 20, 18-21).

O texto de Deuteronômio 5,22-27 retoma o assunto com os mesmos ingredientes: Israel expressa o temor de se confrontar com a glória e a grandeza de Javé e pede a Moisés que seja o mediador de suas palavras: "Tu nos dirás tudo o que Javé nosso Deus te falar. Nós ouviremos e poremos em prática." (Dt 5,27b). A cena apresenta-se particularmente enriquecida com o detalhe de um Deus que, além de sua teofania em meio a fogo, trevas, nuvens e escuridão, escreve as palavras de sua aliança com Israel em duas tábuas de pedra e as entrega a Moisés.

A concepção de que Moisés exerce de modo único a intercessão junto a Javé e media suas palavras, expressa nos livros do Êxodo e do Deuteronômio, deve ter vindo de antigas tradições efraimitas, 4 conforme se pode ler no antigo poema de Números 12. Em reprimenda a Maria e Aarão, que murmuraram contra Moisés, diz Javé:

${ }^{4}$ Sobre a tradição profética efraimita e a concepção de Moisés como profeta, leia-se Wilson, 1993, p. 129-229.

Horizonte, Belo Horizonte, v. 14, n. 42, p. 315-336, abr./jun. 2016 - ISSN 2175-5841 
Ouvi, pois, as minhas palavras:

Se há entre vós um profeta,

é em visão que me revelo a ele,

é em sonho que lhe falo.

Assim não se dá com o meu servo Moisés,

a quem toda a minha casa está confiada.

Falo-lhe face a face,

claramente e não em enigmas,

e ele vê a forma de Javé. (Nm 12,6-8).

A leitura desses textos permite destacar pelo menos três aspectos ou "critérios" teológicos que estão na raiz da formação do cânon bíblico judaico: a auto-revelação de Javé a Israel, a mediação profética de Moisés e a entrega por escrito das palavras da aliança. Assim, os ordenamentos éticos e cultuais que constituem boa parte da Torá, ainda que constructos culturais de distintos momentos históricos, foram acolhidos por Israel como revelação originária da palavra santa de Javé. Se Deus é santo, suas palavras são santas, assim como são sagradas as escrituras que codificam essas palavras.

Ocorre que a Torá não contém apenas textos de caráter jurídico. As narrativas acerca da aliança entre Javé e a "casa de Moisés", que servem de pretexto e pano de fundo aos códigos jurídicos do Pentateuco, representam apenas uma das raízes fundadoras do antigo Israel. Em consonância com os hibridismos tribais que se podem identificar na formação do Israel bíblico, as narrativas do êxodo do grupo de Moisés se fundirão com as sagas das migrações dos patriarcas abrâmicos e com outras histórias locais. Ao fim e ao cabo, a Torá se apresentará como rico entrelaçamento de leis e história; e a concepção de revelação que subjaz aos textos jurídicos, os sábios de Israel a estenderam ao chamado de Abraão e à mesma criação do mundo e do homem. Em resumo, o tema da revelação de Javé a Israel no chamado dos pais e, de modo eminente, na aliança do Sinai constituirá o traço teológico fundante do cânon bíblico. De qualquer modo, Moisés e a saga do êxodo ocuparão lugar de destaque não só na Torá como em toda a Bíblia. Não por acaso, Moisés carrega a paternidade honorífica da Torá, sendo-lhe atribuída pela 
tradição judaica até mesmo sua escrita.5 E a Torá será acolhida como o primeiro corpus de textos do cânon judaico da Bíblia.

\subsection{Nos caminhos da Torá: Nebiim (Profetas) e Ketubim (Escritos) ${ }^{6}$}

Além da Torá, a Bíblia judaica traz duas outras coleções de escritos, conhecidas como Nebiim (Profetas) e Ketubim (Escritos). Sua presença no cânon pode ser explicada, do ponto de vista das motivações teológicas, pela estreita correlação que estabelecem com o tema da revelação/aliança no Sinai e com a mediação profética exercida por Moisés. Vejamos como se mostra tal correlação.

Os Nebiim compreendem duas coleções de livros que os judeus nomeiam respectivamente de Profetas Anteriores (Josué, Juízes, 1 e 2 Samuel, 1 e 2 Reis mais a obra cronista posteriormente acrescida) e Profetas Posteriores (Amós, Oseias, Isaías, Jeremias e os demais livros proféticos). Os Nebiim bíblicos, que representam quantitativamente a metade dos textos da Bíblia judaica, retratam na forma literária de oráculos, sagas, lendas e "história" o que significou a atividade profética, desde o período tribal até o período persa: um reiterado chamado de Israel a ser fiel à aliança. Justamente aí se estabelece sua conexão teológica com a Torá.

$\mathrm{Na}$ origem da extensa linhagem de homens e mulheres que exerceram a atividade profética coloca-se Moisés. A demarcação desse lugar fundante pode ser encontrada em antigos poemas e cânticos, conforme já se apontou em relação a Números 12: Moisés é o único com quem Javé se entretém face a face. Dentre as diversas coleções de leis que constituem o chamado Código Deuteronômico (Dt 1226), encontra-se a unidade (Dt 16,18 a 18,22) que trata das responsabilidades e privilégios de vários portadores de ofícios, como juízes, levitas, reis e profetas. No

\footnotetext{
${ }^{5}$ Curiosamente, a tradição judaica compreendeu, no extremo, que até mesmo o fato de Moisés narrar a própria morte, como aparece em Deuteronômio 34, fazia parte de suas prerrogativas proféticas.

${ }^{6}$ Para designar as três grandes coleções de livros da Bíblia judaica, optamos por utilizar a forma portuguesa mais simples, sem nos preocuparmos com as normas usuais de transliteração do hebraico bíblico.
}

Horizonte, Belo Horizonte, v. 14, n. 42, p. 315-336, abr./jun. 2016 - ISSN 2175-5841 
trecho dedicado aos profetas, encontramos um detalhe que traduz de modo expresso o critério demarcador do ofício profético: a referência a Moisés. "Javé teu Deus suscitará um profeta como eu no meio de ti, dentre os teus irmãos, e vós o ouvireis.” (Dt 18,15, itálico nosso).

Ainda que, ao longo da história do Israel bíblico, o critério da atividade profética tenha se mantido o mesmo - mediar a aliança como Moisés -, a missão profética deu-se com diferentes graus de complexidade. Referindo-se aos diversos contextos e modos como se efetivou o mister profético, Gruen (1985, p. 126) avalia que, no período tribal, quando as divindades dos povos cananeus e de outras nações vizinhas rivalizavam com Javé, cabia ao profeta defender a pureza da fé israelita. Depois, nos primeiros tempos do período monárquico, a idolatria penetrou em Israel no bojo de acordos políticos e comerciais firmados com nações vizinhas. Nesse contexto, o profeta precisava ser muito coerente com sua fé, para não se deixar engolir. Por fim - continua o autor -, no auge do imperialismo assiro-babilônico, "a idolatria passou a ser inoculada nos submetidos, sem deixarlhes alternativa. Resistir equivalia em determinados setores não somente a uma grande ingenuidade, senão a subversão ou a alta traição". (GRUEN, 1985, p. 126). Ser profeta nesse contexto requeria heroísmo.

Em todos esses diferentes momentos, a palavra profética sempre se guiou pela exigência de fidelidade à aliança com Javé. Não por acaso, de Oseias a Ezequiel, a metáfora do casamento/traição será uma constante nos textos proféticos: o casamento, para se referir à iniciativa de amor de Javé em favor de sua noiva Israel; traição e prostituição, para falar da infidelidade de Israel a seu Deus. Dentre as inúmeras passagens bíblicas que falam disso de modo expresso, pode-se ler, à guisa de ilustração, a minuciosa história simbólica de Jerusalém, em Ezequiel 16; ou as boas lembranças do tempo de noivado, em Jeremias 2. Na mesma linha, o critério que estabelece distinção entre verdadeiros e falsos profetas recorre ao tema da aliança mediada por Moisés no Sinai. Sob o mesmo critério compreende-se a avaliação dos reis de Israel e Judá que estrutura os dois livros dos Reis. Da mesma 
forma, as reformas político-religiosas associadas ao governo dos reis Ezequias e Josias, conforme se narra em 2Reis 18-20 e 21-23, se sustentam num movimento de retorno à Torá. (Leia-se 2Rs 23, 1-3). A solene leitura da Lei (em Ne 8), no contexto da reforma de Esdras e Neemias, segue o mesmo caminho. A propósito, foi no contexto da reconstrução da comunidade judaica, na época do domínio persa, que a Torá praticamente ficou pronta. Na mesma sintonia, o memorial da revelação/aliança de Deus no evento êxodo/Sinai constituirá o substrato teológico que dará aos Nebiim seu lugar no cânon judaico das escrituras.

Em consonância com o tema fundante da revelação/aliança, a constituição do cânon judaico da Bíblia orientou-se basicamente pelos critérios de autoridade e antiguidade. Sob esses critérios, acolheram-se como sagrados os livros considerados de origem mosaica ou profética, considerando-se encerrada a cadeia da sucessão profética aí pelo final do século V a.E.C. (TREBOLLE BARRERA, 1996, p. 181). Entretanto, o cânon judaico ainda não estava pronto. Certamente, a cessação da profecia favoreceu a que sábios judeus do período persa e de épocas posteriores coligissem grande volume de material da era monárquica. A palavra de Javé será buscada não mais na viva voz dos profetas, mas nos escritos da tradição processo a que podemos chamar de "biblificação" da palavra de Deus. (CANTARELA, 2013, p. 914). No bojo desse movimento, o cânon judaico das escrituras será enriquecido com os outros Escritos (Ketubim).

Os Ketubim (Escritos) constituem uma coletânea de caráter basicamente sapiencial formada pelos livros de Salmos, Jó, Provérbios, Rute, Cântico dos Cânticos, Eclesiastes, Ester e Daniel. Alguns desses livros ou partes deles são relativamente antigos e circularam paralelamente a coletâneas que formam a Torá ou os Profetas. O livro de Salmos (Tehilim), por exemplo, que encabeça os Ketubim, pode ser situado num lugar fronteiriço entre Profetas e Escritos, uma vez que originalmente pertencera à coletânea dos Profetas Anteriores. Outros, como Eclesiastes, Cântico dos Cânticos e Ester foram objeto de prolongada discussão entre escolas rabínicas quanto à sua canonicidade. Em que pesem as discordâncias 
rabínicas e as evidentes diferenças entre os Ketubim e as outras duas coleções canônicas, do ponto de vista teológico pode-se identificar no cânon um caráter unitário marcado por um movimento que passa pelo tema do êxodo/revelação/aliança. Literariamente, esse movimento determinará tensões entre lei e profecia, êxodo e exílio, criação e tempos escatológicos. (TREBOLLE BARRERA, 1996, p. 200-201).

Sob o pressuposto dessa unidade, o livro dos Salmos ocupa lugar central na Bíblia. Pode-se dizer que os Salmos entrelaçam a Torá, os Profetas e os outros Escritos em forma de oração. Assim, encontramos nesse livro o louvor a Javé pela criação, pela escolha de Israel, pela terra, por Sião, pelas grandes instituições nacionais. Vários salmos louvam a Javé pela Lei e pelos justos que a praticam. Há salmos que louvam a Javé pela vitória frente aos inimigos; e inúmeros outros que, no contraponto, pedem a Javé o socorro, a proteção e a restauração da nação destruída e exilada. Como nos Profetas, não faltam as inúmeras referências à infidelidade de Israel. Destacamos, sobretudo, alguns salmos que constituem verdadeiras sínteses da história de Israel, nos quais se louva a Javé pelas maravilhas em seu favor, de modo particular em relação à experiência fundante do êxodo. Sob esse viés podem ser lidos os salmos 77, 78, 81, 90 (único salmo atribuído a Moisés), 95, 103, 105, 106, 135, 136.

A perspectiva sapiencial que marca os Escritos certamente bebeu na fonte da Torá e dos Profetas. Assim, Cântico dos Cânticos celebra em linguagem densamente simbólica o namoro entre Javé e Israel. O autor de Jó tece uma sofisticada crítica a certa leitura tacanha da lei deuteronômica.7 Provérbios e Eclesiastes entendem a sabedoria como senda de justiça, caminho querido por Javé. Enfim, aí pelo século I a.E.C., um livro (o Eclesiástico ou Sirácida), que acabou não fazendo parte do cânon judaico, trará em seu prólogo um elogio à

\footnotetext{
${ }^{7}$ Nesse escrito bíblico, os amigos de Jó encenam uma perspectiva estreita de leitura da lei deuteronômica. Tal perspectiva, certamente fundada na leitura literal de versos como o de Ex 20,5-6, explica o sofrimento como castigo divino. Contrapondo-se a essa visão, a personagem de Jó esperneia e insiste num outro caminho de encontro com Javé.
} 
sabedoria de Israel pelas "tantas e tão grandes lições" oferecidas pela Lei, pelos Profetas e pelos outros Escritos que se seguiram.

Naquele momento, a tríade canônica estava praticamente pronta. O longo processo de sua formação histórica e sua recepção nos ambientes judaicos e cristãos sugerem, para o propósito deste artigo, algumas perguntas: qual a importância que esses escritos tiveram, enquanto norma de vida, para o Israel dos tempos bíblicos? Como as primeiras comunidades cristãs leram essas escrituras? Será o assunto do próximo tópico.

\section{A recepção da Lei, dos Profetas e dos Escritos}

O tema da revelação/aliança no Sinai, em estreita correlação com as tradições sobre Moisés e o êxodo, constituiu o cerne das motivações teológicas que conduziram certas narrativas do antigo Israel ao lugar de textos canônicos para a vida social e religiosa da comunidade. Foi o que vimos nos tópicos anteriores. Ao longo dos séculos, à medida que suas tradições históricas iam sendo escritas e coligidas - e celebradas e relidas sob uma compreensão religiosa da existência -, os israelitas/judeus não se preocuparam com questões relacionadas ao processo literário de sua compilação. A importância política e social de instituições - como a corte, o templo, os círculos proféticos, as escolas de sábios - às quais coube recolher, compilar e guardar aquelas tradições históricas, por si, conferia ao material valor de sacralidade. Também para os primeiros cristãos o processo histórico de escrita da Bíblia não foi objeto de suas preocupações. A propósito, a lida estrita e sistemática com esse tipo de questão só a encontraremos na ciência bíblica moderna.

Referindo-se ao modo como os judeus do século I liam suas escrituras - o que seguramente podemos estender aos cristãos de matriz judaica - o teólogo e especialista em patrologia Ramón Trevijano resume que, ainda que não faltasse certo interesse pelos autores humanos, aqueles judeus 
liam os livros como documentos fundamentais de sua vida religiosa. A crítica literária não entrava no âmbito de suas preocupações intelectuais nem de sua preparação cultural. O importante era que esses livros transmitiam as revelações divinas, refletiam sobre elas e as pregavam. $\mathrm{O}$ fundamental era que, em última instância - e por que não na primeira? -, sua origem estava em Deus. Deus era quem tinha falado pela boca dos profetas e Deus era o autor principal dos livros sagrados, que se tinha servido dos hagiógrafos como instrumento. (TREVIJANO E., 2009, p. 3233).

Sob tal perspectiva, os judeus, assim como os cristãos dos primeiros tempos, compreenderam o cânon em seu sentido metafórico de norma, regra de vida. ${ }^{8}$ Mais que uma lista de livros autorizados, representativos de sua história, os escritos canônicos foram recebidos sob o signo da normatividade.

\subsection{A Bíblia como norma de vida para a comunidade judaica}

Encontramos no imaginário religioso do antigo Israel a associação entre “separar" e "santificar". Inúmeras passagens bíblicas acerca das oferendas das primícias do gado e das colheitas indicam isso. (Leia-se, por exemplo, Dt 26, 1-11). Encontramos também textos que falam da separação de pessoas para o serviço de Javé, no templo ou como profeta. (Leia-se, dentre inúmeras passagens, a narrativa sobre a consagração de Samuel em 1Sm 1,19-28; ou o belo poema da vocação do profeta Jeremias, em Jr 1,4-10).

Entretanto, a condição de santidade que marca a oferenda ou a pessoa consagrada não advém simplesmente do gesto ritual de separar, mas da pertença a Javé. Segundo a fé de Israel, tal pertença não decorre de um movimento em direção a Javé, senão da iniciativa dele: “Tu és um povo consagrado a Javé teu Deus; foi a ti que Javé teu Deus escolheu para que pertenças a ele como seu povo próprio, dentre todos os povos que existem sobre a face da terra.” (Dt 7,6). É certo que a categoria

\footnotetext{
${ }^{8}$ Etimologicamente, o termo cânon parece associar-se a instrumentos de medida usados na construção. Em sentido metafórico, sugere a ideia de agir "dentro das medidas", o que traz implicada a concepção de algo normativo. Conforme nos informa Trebolle B. (1995, p. 168), Quintiliano (35-95) utilizou o termo cânon para designar a lista de autores clássicos estabelecida pelos filólogos de Alexandria. Em contexto cristão, com o sentido de configurar uma lista de livros revelados/inspirados, a aplicação do adjetivo canônico aos livros bíblicos vem do Concílio de Laodiceia (meados do século IV). (SÁNCHEZ C., 1996, p. 58).
} 
religiosa "povo escolhido" ou "povo de Deus", com que o antigo Israel se autocompreendeu perante outros povos, mostra-se hoje particularmente problemática, em vista do reconhecimento do valor da plural experiência religiosa. De qualquer forma, foi daquela compreensão que a comunidade judaica hauriu forças para sobreviver aos vários impérios que a submeteram.

A correlação entre santidade e pertença a Javé pode ser encontrada também no modo como os judeus compreenderam suas escrituras sagradas. Para a comunidade judaica, a santidade das escrituras não decorre da mera separação de alguns textos do mundo profano para consagrá-los ao nível das sacralidades. Em relação a isso, ao discutir a correlação entre as categorias teológicas "palavra de Deus" e "sagradas escrituras", Artola (2005, p. 43) explica que "se a Escritura é denominada santa, a origem de tal condição deve ser procurada em alguma vinculação misteriosa com a santidade de Deus”.

Ora, a exigência de "ser santo como Javé é santo", expressa pelas escrituras sagradas, não se desvincula da história. Daí seu caráter normativo para a vida cotidiana da comunidade. Não se trata de uma compreensão da norma direcionada apenas para o fazer teológico e para a vida da fé expressa nos ritos e no culto. Trata-se, bem mais, da disposição ativa por tomar a norma como orientação e medida para a vida social em sua totalidade. Nos momentos especiais configurados pelos ritos cotidianos e pelas grandes festas anuais, Israel celebrava a aliança com Javé e sua proteção nos acontecimentos de sua história. Nesse memorial Israel encontrava os elementos de que necessitava para avaliar e compreender os acontecimentos do seu presente, fossem os de amplitude nacional, fossem aqueles da miudeza do cotidiano.

Tanto no âmbito estritamente relacionado às festas religiosas e ao culto quanto no cotidiano da vida, a recepção normativa das tradições (histórias, leis, oráculos proféticos, sabedoria) apresenta-se, no mundo bíblico, sob dois vieses característicos: o cultual e o ético. A perspectiva cultual, construída a partir de diferentes tradições sacerdotais e relacionada a determinados locais de culto, dá 
especial atenção ao ritual dos sacrifícios, à investidura dos sacerdotes, às regras referentes ao puro e ao impuro. A motivação religiosa reiteradamente expressa nesse viés fundamenta-se na afirmação da santidade de Javé. Na Bíblia, esta perspectiva apresenta-se bem representada (mas não exclusivamente) pelo livro do Levítico. A perspectiva ética, por seu lado, pode ser particularmente destacada no livro do Deuteronômio. Sua motivação religiosa de fundo atrela-se à memória do êxodo e o foco principal dirige-se às relações sociais.

A costura dessas diferentes tradições nos textos narrativos e jurídicos que formam a Torá deu ao conjunto interessante entrelaçamento entre religião e vida social. Não podia ser diferente numa sociedade que compreendia a totalidade de sua existência pelo viés do sagrado. A cada página, mesclam-se, sem hierarquias, as normas de pureza, os preceitos morais relativos à sexualidade, à família e ao casamento, as medidas em favor do assalariado, as normas de justiça relativas ao ano sabático, as normas para a realização das grandes festas anuais e do sábado, as exigências de justiça para com o pobre e o estrangeiro. Assim, por exemplo, em que pese o aparente excesso da lei de talião ( $\operatorname{lv}$ 24, 19-22; Ex 21-22), a indenização pelas perdas causadas ao próximo se justifica pela exigência de "ser santo como Javé é santo" e ainda porque Javé é aquele que fez Israel "sair da terra do Egito, da casa da escravidão”. As duas justificativas constituem quase que um refrão da Torá. Por vezes, o estribilho amplia-se em solenes sínteses:

Interroga os tempos passados, que te precederam, desde o dia em que Deus criou o homem sobre a terra: de uma ponta do céu até a outra, existiu já uma coisa tão grande como esta? Ouviu-se algo de semelhante? Existe um povo que tenha ouvido a voz do Deus vivo falando do meio do fogo, como tu a ouviste, e que tenha permanecido vivo? Ou um deus que tenha vindo para tomar para si uma nação do meio de outra nação, com provas, sinais, prodígios e combates, com mão forte e braço estendido, por meio de grandes terrores - como tudo o que Javé vosso Deus realizou no Egito, em vosso favor, aos vossos olhos? (Dt 4,32-34)

Se na Torá os vieses ético e cultual se entrelaçam na construção da norma, nos Profetas, particularmente nos Profetas Posteriores, sua relação apresenta-se sob tensão. Assim, dentre inúmeras outras passagens bíblicas, o poema que abre o 
livro de Isaías condena a hipocrisia de Israel através de expresso contraponto entre culto e prática da justiça:

Que me importam os vossos inúmeros sacrifícios?, diz Javé. Estou farto de holocaustos de carneiros e da gordura de bezerros cevados; no sangue de touros, de cordeiros e de bodes não tenho prazer. Quando vindes à minha presença quem vos pediu que pisásseis meus átrios? Basta de trazer-me oferendas vãs: elas são para mim incenso abominável. Lua nova, sábado e assembleia, não posso suportar falsidade e solenidade. [...] Cessai de praticar o mal, aprendei a fazer o bem! Buscai o direito, corrigi o opressor! Fazei justiça ao órgão, defendei a viúva. (Is 1,11-17).

Da mesma forma, em Jeremias, de modo ainda mais contundente, as invectivas proféticas se dirigem até mesmo contra a venerável instituição do Templo da era monárquica:

Melhorai os vossos caminhos e as vossas obras, e eu vos farei habitar neste lugar. Não vos fieis em palavras mentirosas dizendo: "Este é o Templo de Javé, Templo de Javé, Templo de Javé!" Porque, se realmente melhorardes os vossos caminhos e as vossas obras, se realmente praticardes o direito cada um com o seu próximo, se não oprimirdes o estrangeiro, o órfão e a viúva, se não derramardes sangue inocente neste lugar e não correrdes atrás dos deuses estrangeiros para vossa desgraça, então eu vos farei habitar neste lugar, na terá que dei a vossos pais há muito tempo e para sempre. (Jr 7, 3-7. Leia-se todo o capítulo).

Há inúmeras outras passagens. Mas julgamos que os dois textos citados realçam suficientemente a tensão entre culto e prática da justiça. Mais que isso, ilustram de forma cabal a profunda compreensão que os profetas bíblicos tiveram do sentido da norma: o louvor a Javé passa pelo amor ao próximo, concretizado na prática do direito e da justiça. Foi nessa direção que também Jesus de Nazaré e as primeiras comunidades cristãs leram as escrituras.

\subsection{A recepção das escrituras por Jesus e pelas primeiras comunidades cristãs}

Basta uma rápida entrada nas pesquisas sobre o Jesus histórico ${ }^{9}$ para nos convencermos de que aquele homem sobre quem se assenta o cristianismo era um

\footnotetext{
${ }^{9}$ Dentre as inúmeras abordagens sobre as relações entre Jesus e o judaísmo, sugerimos a de Geza Vermes (1924-2013), pesquisador britânico de origem judaica húngara. Dentre sua extensa obra, indicamos A religião de Jesus, o judeu (1995) e Jesus e o mundo do judaísmo (1996). Para um estudo das instituições judaicas do século I, vale ler o já clássico Jerusalém no tempo de Jesus, do biblista luterano Joachim Jeremias (1900-1979).
}

Horizonte, Belo Horizonte, v. 14, n. 42, p. 315-336, abr./jun. 2016 - ISSN 2175-5841 
judeu fiel à Lei de Moisés, não propriamente um doutor da lei, nem escriba, nem sacerdote, mas um mestre de sabedoria. Os evangelhos, submetidos aos filtros da crítica histórica e de outras ciências bíblicas, certamente não podem ser compreendidos como história de Jesus, em sentido estrito. Constituem, mais exatamente, um gênero narrativo que coligiu e atualizou as tradições orais sobre Jesus nos novos contextos em que iam se organizando as comunidades cristãs formadas por discípulos da segunda ou terceira geração. De qualquer forma, não há como alcançar uma compreensão mais ampliada de qualquer página dos evangelhos sem que se leve em conta sua relação com o mundo do judaísmo do século I. Em que pese o volume de perguntas e lacunas que os estudos críticos do período ainda não responderam, não há como não reconhecer Jesus como um judeu profundamente religioso. Para além de frequentar a sinagoga e participar das festas anuais de peregrinação ao templo de Jerusalém - práticas que qualquer judeu devia observar -, sua vivência da fé judaica caracterizou-se sobretudo pela fidelidade ao espírito da Torá e dos Profetas.

No embate com autoridades religiosas do judaísmo de então, cuja leitura da Torá se fazia por demais legalista e literal, Jesus responde com uma fala de sabedoria que se pode compreender como a síntese da autêntica obediência à Lei: “O sábado foi feito para o homem e não o homem para o sábado.” (Mc 2,27). ${ }^{10}$ Da mesma forma, quando lhe perguntam sobre o maior dos mandamentos, Jesus responde ${ }^{11}$ com duas citações da Torá: os versos iniciais do Shemá (Dt 6,4-5) e o verso (Lv 19,18b) que resume a lista de prescrições morais de Levítico 19.

Na mesma direção, os contrapontos entre fidelidade e infidelidade à aliança com Deus, encenados por personagens de inúmeras parábolas, chegando a rasurar

\footnotetext{
${ }^{10}$ No evangelho de João $(5,1-18)$ podemos ler uma passagem em que ao legalismo dos judeus acerca do sábado Jesus contrapõe-se com uma ação libertadora. Vale observar, an passant, que o azedume contra "os judeus" e a perspectiva cristológica de alto nível de elaboração, presentes na passagem e típicos do evangelho de João, remetem ao contexto redacional desse evangelho, próximo do ano 100, quando o movimento cristão se apresenta em franco rompimento com sua matriz judaica.

${ }_{11}$ Parece que a fórmula que constitui a "regra de ouro" da Torá já era conhecida. Consta que o sábio fariseu Hillel, falecido aí pelo ano 10, a tenha utilizado para ensinar a Torá a um gentio que pretendia tornar-se judeu. Reza a lenda que o gentio pedira ao mestre que sua catequese não durasse mais que o tempo em que ele (o gentio) desse conta de ficar equilibrado numa única perna. A mesma lenda associa-se também a outro sábio judeu, Shamai, contemporâneo de Hillel. Sobre as divergências entre shamaítas e hilelitas acerca dos prosélitos (gentios convertidos ao judaísmo), leia-se Jeremias (2010, p. 423-442).
} 
a interpretação douta da autoridade religiosa, indiciam a liberdade de espírito e a grande desenvoltura com que Jesus interpretou e viveu sua religião. A leitura da parábola do "filho pródigo" (Lc 15, 11-32) ou a do administrador infiel (Lc 16, 1-8) se o leitor fizer o esforço de identificar essas personagens com o próprio Jesus -, certamente permite inferir sobre a liberdade religiosa com que Jesus obedeceu à Lei. Na aparente desobediência à vontade de Deus, representado pelas personagens do pai e do patrão - desobediência demarcada pelo olhar legalista da autoridade religiosa -, Jesus, qual filho ou servo esbanjador, cumpre a vontade do Pai distribuindo seus bens a quem menos merece: prostitutas e pecadores. Outras parábolas podem ser lidas sob este viés. A propósito, a obediente desobediência de Jesus apresenta-se como traço central dos evangelhos.

Não por acaso, os discípulos da segunda ou terceira geração de seguidores de Jesus viram em suas palavras e ações o pleno cumprimento da Torá e dos Profetas. (Leia-se Mt 5, 17-19). A linguagem bíblica que traduz o anseio por renovar a aliança com Javé não foi uma invenção cristã. Ela já aparece nos profetas, desde os antigos oráculos de Oseias (Os 3) aos poemas messiânicos mais recentes de Jeremias (Jr 3, 12-13) ou Ezequiel (Ez 11, 14-21 e Ez 37). Serão aqueles cristãos no entanto que, ao realizarem a leitura da escrituras judaicas relacionando-as com a pessoa de Jesus, darão corpo teológico e literário a um Novum Testamentum (tradução latina de "nova aliança”).

Do ponto de vista teológico, a nova aliança com Javé se realizava não mais como memorial do êxodo ou retorno à obediência das palavras recebidas no Sinai, senão no seguimento de Jesus, a encarnação da palavra de Javé numa pessoa histórica. Nas concepções antropológicas do antigo Israel, compreende-se a palavra - em hebraico, dabar - não apenas como discurso exteriorizado, senão como evento performático, eficaz, criativo, criador de novos eventos. Dabar significa ao mesmo tempo a palavra dita, o sucedido, a narração da história e a pessoa mesma cuja palavra convoca o acontecer. Assim, os cristãos originários do ambiente judaico reconhecerão nas palavras e nas ações de Jesus o dabar de Javé, o agir de 
Deus na (ou através da) história concreta de Jesus- concepção que o evangelho de João traduzirá pela fórmula “o Verbo se fez carne e habitou entre nós”. (Jo 1, 14).

O seguimento de Jesus e a memória histórica construída em torno de suas palavras e ações ensejaram um movimento de expansão missionária cujo fruto literário chamamos, por metonímia, Novo Testamento. Assim o Novum Testamentum será não apenas a nova aliança de Javé realizada pela mediação histórica de Jesus de Nazaré, mas também certo número de escritos originados da memória construída em torno de sua pessoa - lidos, também estes, como dabar de Deus. Somados ao extenso material da herança judaica, formarão o cânon cristão da Bíblia.

Nos escritos do Novo Testamento, a compreensão de que Jesus dá pleno cumprimento à Torá e aos Profetas apresenta-se com matizes diversos. Os escritos de Paulo, por exemplo, tecem tenso contraponto entre a justificação pela fé em Cristo e a justificação pelas obras da Lei. Leia-se Gl 2,15-21 ou Gl 3,19 a 4,7, onde Paulo discute o papel pedagógico (agora desnecessário) da Lei. Quer no nível da formulação teológica, quer na resposta a problemas pastorais concretos (como se pode ler em 1Cor), as cartas de Paulo contrapõem aos mandamentos da Torá a "lei de Cristo", lei interior, lei da liberdade.

Escritos depois das cartas de Paulo, os evangelhos constituem importantes documentos dos cristianismos originários, particularmente das últimas décadas do século I. Giram em torno de Jesus: seus ditos de sabedoria, sua releitura da Torá, sua compreensão do reino de Deus, suas parábolas, sua atenção aos pequenos, seus milagres, sua morte/ressurreição. Em tudo isso, a referência à Torá e aos Profetas apresenta-se uma constante. Para ficar em alguns exemplos: Em Mateus 5, a referência à montanha e as inúmeras citações das escrituras judaicas remetem à tradição mosaica, utilizando-se de um gênero muito conhecido no ambiente judaico, a halaká, um modo de debater e atualizar os textos da Torá. No evangelho de João, a conhecida passagem das núpcias de Caná (Jo 2,1-11) retoma, sob o viés 
cristão, o conhecido mote do casamento entre Deus e Israel. A cena, rica de detalhes, assenta-se sobre o constructo teológico representado pelo "egó eimí” (Eu Sou) que atravessa todo o evangelho. Insiste o Jesus de João: eu sou a luz do mundo, eu sou a porta por onde entram as ovelhas, eu sou o sal da terra, eu sou o caminho... Nas bodas de Caná, ele oferece/é o vinho novo que devolve a alegria à festa de casamento entre Javé e Israel. Ao fim e ao cabo, ainda que a personagem não apareça na narrativa, Jesus é o noivo da nova aliança.

Em resumo: as elaborações teológicas e pastorais construídas pelos cristãos dos primeiros tempos jamais esqueceram suas raízes judaicas. As narrativas sobre o chamado dos patriarcas, a escolha de Israel por Javé, o êxodo, a revelação no Sinai, a mediação de Moisés, as leis, os salmos, a atividade profética, as grandes instituições nacionais e sua perda, a sabedoria... foram lidas e relidas a partir da história de Jesus de Nazaré. E, sob esse novo olhar, marcaram a formação histórica dos escritos do Novo Testamento.

\section{Conclusão}

Destacamos, ao longo do artigo, uma razão teológica que certamente pode ser colocada como explicação primeira para a formação do cânon bíblico: a revelação de Deus. Na tradição religiosa do antigo Israel, a crença na revelação divina foi associada à experiência do êxodo, à mediação do profeta Moisés, à outorga da Lei no Sinai. A constante referência a esses eventos fundadores, situados num tempo primordial da existência histórica de Israel como povo, deixou marcas indeléveis no rico material literário que constitui a Torá, os Nebiim e os Ketubim. Na esteira dessa tradição, os cristãos releram a Torá e os Profetas sob a compreensão de que a revelação de Deus se dá de forma plena na pessoa de Jesus. Das palavras e ações de Jesus e do seu seguimento nasceram os escritos do Novo Testamento. 
Se, do ponto de vista teológico, a delimitação desse critério fundante de canonicidade firma-se como pressuposto indiscutível, o mesmo não se dá quando se aborda a questão do cânon pelo viés de sua história literária e social. ${ }^{12}$ Do ponto de vista de sua história literária, uma das poucas afirmações que podem ser feitas a respeito do cânon, sobre a qual não se pode lançar qualquer dúvida, é que sua formação histórica foi extremamente complexa. Do ponto de vista de sua história social, relacionada ao aspecto de sua recepção normativa, ocorre dificuldade de igual tamanho: justamente porque nunca se apresentou unívoca a compreensão do que vale ou não como norma, judeus e cristãos, cada qual a seu tempo e modo, enfrentaram a complexa tarefa de definir um cânon dentre a diversidade de cânones.

Para o cânon judaico, pode-se afirmar, de modo geral, que fatores de diversa natureza estiveram presentes na definição do cânon bíblico. Sem simplificar demasiadamente a questão, se aceita que o assentimento da comunidade, construído ao longo de muito lembrar e celebrar eventos significativos de sua história, associado a decisões de caráter formal e oficial da liderança religiosa, foi o que fixou definitivamente o cânon. Para a maioria dos grupos judeus (que excluem os escritos deuterocanônicos da tradução grega dos LXX), pode-se considerar fixado o cânon aí pelos meados do século II a.E.C. Vários autores preferem jogar a data para os inícios do século II.

No caso do cristianismo, suas escrituras sagradas foram durante certo tempo apenas os escritos do Antigo Testamento. No final do século II, boa parte dos escritos do Novo Testamento já tinha conquistado grande autoridade no meio das comunidades cristãs. Desse núcleo, fizeram parte as 13 cartas de Paulo ou a ele atribuídas (que já circulavam como coletânea aí pelo ano 120), os evangelhos (primeiro os sinóticos, por último o de João), Atos dos Apóstolos e algumas outras

\footnotetext{
${ }^{12}$ Não cabe aqui apresentar as inúmeras e diferentes teses sobre a formação histórica do cânon bíblico. Para uma visão detalhada e especializada sobre a história literária e social do cânon bíblico, leia-se Trebolle Barrera (1996, p. 175-273). Para os dados históricos presentes nesta conclusão, seguimos este autor.
} 
epístolas (1Pedro e 1 João). A forma definitiva do cânon neotestamentário, basicamente como a conhecemos hoje, vem dos finais do século IV.

Em correlação com a complexa história literária e social do cânon bíblico, colocam-se diversas questões de interesse teológico e pastoral. Uma das mais contundentes diz respeito ao processo mesmo de formação do cânon, que nasce do plural e multifacetado assentimento das comunidades para finalmente cristalizarse numa unidade definida pela autoridade religiosa. Seria a fixação final do cânon (bíblico ou qualquer outro) a expressão de poder de determinados grupos dentro de uma tradição religiosa?

Outra questão, que tange as discussões sobre o cânon, correlaciona-se ao modo como a coletânea dos Profetas Anteriores foi recebida nas edições cristãs da Bíblia. Chamar a grande obra deuteronomista (Josué, Juízes, 1-2 Samuel e 1-2 Reis) de "Livros Históricos" cria o risco de perder de vista importantes chaves de leitura desses escritos. O excessivo interesse pela história do período tribal e da monarquia pode desviar para um historicismo desnecessário para a meditação do texto bíblico; e deixar esquecidas figuras como Josué, Débora, Samuel, Natã, Elias e Eliseu, de fundamental importância para que o texto bíblico faça pensar.

Uma última questão correlaciona-se ao modo como se realiza a leitura do texto bíblico no meio eclesial. Seja por razões litúrgicas, seja no âmbito de “campanhas" eclesiais, seja por iniciativa individual, lemos a cada vez não mais que trechos, excertos, passagens de textos bíblicos. Buscamos aqueles livros, capítulos, perícopes, versículos que podem sustentar e revestir de autoridade nosso próprio discurso. Escolhemos passagens bonitas, libertadoras, falantes... E acabamos criando um cânon dentro do cânon. O risco de leitura fundamentalista torna-se iminente. 


\section{REFERÊNCIAS}

ARTOLA, Antonio M. A Bíblia, Palavra de Deus. In: ARTOLA, Antonio M. ; SÁNCHEZ CARO, José Manuel. A Bíblia e a palavra de Deus. 2.ed. São Paulo: Ave-Maria, 2005. p. 21-51.

BÍBLIA DE JERUSALÉM. (Edição revista e ampliada. Tradução das introduções e notas de La Bible de Jérusalem, edição de 1998). São Paulo: Paulus, 2002.

CANTARELA, Antonio Geraldo. A 'biblificação' das narrativas sagradas: riscos e ganhos. In: 26 Congresso Internacional da Sociedade de Teologia e Ciências da Religião, 2013, Belo Horizonte, MG. Deus na sociedade plural: fé, símbolos, narrativas: anais do Congresso da Soter. Belo Horizonte: PUC Minas, 2013. p. 911-919.

FERRY, Luc. Ciência e "não ciência": a questão do critério de demarcação - O racionalismo crítico de Kant e Popper. In: FERRY, Luc; VINCENT, Jean-Didier. O que é o ser humano? Sobre os princípios fundamentais da filosofia e da biologia. Petrópolis, RJ: Vozes, 2011. p. 85-107.

GRUEN, Wolfgang. O tempo que se chama hoje: uma introdução ao Antigo Testamento. 8.ed. São Paulo: Paulinas, 1985.

GUNNEWEG, Antonius H.J. Teologia bíblica do Antigo Testamento: uma história da religião de Israel na perspectiva bíblico-teológica. São Paulo: Teológica; Loyola, 2005.

JEREMIAS, Joahim. Jerusalém no tempo de Jesus: pesquisas de história econômicosocial no período neotestamentário. Santo André: Academia Cristã; São Paulo: Paulus , 2010.

TREBOLLE BARRERA, Julio. A Bíblia judaica e a Bíblia cristã: introdução à história da Bíblia. Petrópolis: Vozes, 1996.

SÁNCHEZ CARO, José Manuel. O cânon da Bíblia. In: ARTOLA, Antonio M. ; SÁNCHEZ CARO, José Manuel. A Bíblia e a palavra de Deus. 2.ed. São Paulo: Ave-Maria, 2005. p. 53-125.

TREVIJANO ETCHEVERRÍA, Ramón. A Bíblia no cristianismo antigo: pré-nicenos, gnósticos, apócrifos. São Paulo: Ave-Maria, 2009.

VERMES, Geza. A religião de Jesus, o judeu. Rio de Janeiro: Imago, 1995.

VERMES, Geza. Jesus e o mundo do judaísmo. São Paulo: Loyola, 1996.

WILSON, Robert R. Profecia e sociedade no antigo Israel. São Paulo: Paulinas, 1993. 